\title{
Is duration of exposure a determinant factor for genotoxicity and clinical manifestations induced by Formaldehyde?
}

\author{
Manal H. Abdel Aziz ${ }^{1}$, Elsayed A. Metwally ${ }^{2}$, Eiman Ibrahim Ahmed Zaki ${ }^{3}$, Omnia A. Azzaz ${ }^{1}$, Heba A. Hussein ${ }^{1}$ \\ ${ }^{1}$ Departments of Forensic Medicine \& Clinical Toxicology, Faculty of Medicine, Alexandria, Egypt. \\ ${ }^{2}$ Human Anatomy and Embryology, Faculty of Medicine, Alexandria, Egypt. \\ ${ }^{3}$ Histology and Cell Biology, Faculty of Medicine, Alexandria, Egypt.
}

\begin{abstract}
Introduction: Formaldehyde is a naturally occurring compound extensively used as cadavers' preservative in medical schools anatomy departments. The International Agency for Research on Cancer (IARC) classifies formaldehyde as carcinogenic to humans (group 1). Aim of the work: To examine duration of exposure as a determining factor in genotoxicity of formaldehyde exposure using the micronucleus test, correlate clinical manifestations with genotoxic effects, and measure formaldehyde air levels in dissecting rooms of Alexandria Faculty of Medicine, Egypt. Materials and methods: A pre-designed questionnaire was filled for each subject to assess clinical signs and symptoms of exposure and to screen for exclusion criteria. Buccal epithelial cells were collected; twice from 40 undergraduate students before and after one month of exposure, and once from 10 staff members who had participated in anatomy classes. Cells of both groups were stained using Feulgen method and micronucleus test (MN) was applied. The air levels were measured in 3 anatomy labs using MIRAN-IR. Results: Mean frequency of micronuclei was significantly higher in staff group $(2.60 \pm 1.26) / 1000$ cells than the control and student groups $(0.80 \pm 0.76) / 1000$ cells, $(1.05 \pm 1.28) / 1000$ cells respectively with $\mathrm{p}=0.001$. Significant positive correlation between frequency of $\mathrm{MN}$ and skin, eye and respiratory symptoms. The mean level of airborne formaldehyde in 3 dissecting rooms was $7.2 \pm 6.9 \mathrm{ppm}$ which is above OSHA recommendations. Conclusion: Duration of exposure is an important determinant in genotoxiciy of formaldehyde exposure. Clinical manifestations of formaldehyde exposure were correlated to the MN frequency. Studied participants are exposed to high concentrations of formaldehyde above the standard levels according to time of exposure. Efforts have to be made to improve air quality and reduce exposures during anatomy classes.

Key words Formaldehyde, micronucleus tests, genotoxicity, duration of exposure, anatomy classes, buccal epithelial cells
\end{abstract}

\section{Introduction}

$\mathrm{F}$ Tormaldehyde (FA) is widely used in medical field to preserve cadavers in departments of anatomy. It helps to maintain a life-like state of the cadavers and keeping the normal anatomical relations needed for dissection. Consequently, medical students and anatomists are regularly exposed to high levels of FA in the dissection halls (Golden, 2011\&Onyije and Avwioro, 2012\& da Costa, 2014).

Upon exposure, FA enters the body by inhalation or through the skin. The high solubility of FA in water makes it rapidly absorbed in the nose and the higher parts of the lungs. Once absorbed, it is rapidly broken down and converted to a non-toxic chemical known as formate (Nielsen et al., 2013).

According to the Occupational Safety and Health Administration, The permissible exposure limit
(PEL) of FA in the workplace is $0.75 \mathrm{ppm}$ measured as an 8-hour time-weighted average (TWA). While the short-term exposure limit (STEL) is 2 ppm, which is the extreme exposure permissible through a 15-minute period. On the other hand, the PEL of FA exposure according to the Egyptian law is 0.3 ppm (Kashyap and Reddy, 2012).

FA as a reactive gas is irritant to eyes, nose and throat. The resultant manifestations include burning, pain or itching and lacrimation. Moreover, dermal exposure to FA may cause itching and rash. However, whatever the physical form of FA, toxic actions start after gaseous FA is dissolved in water (Kim et al., 2011; Kumaraswamy et al., 2011).

In 2005, The International Agency for Research on Cancer (IARC) reported FA as carcinogenic agent. It 
can cause nasopharyngeal cancer in humans and as a result it was found "strong but not enough evidence" for leukemia. Recently, in 2012, IARC classified it as carcinogenic in humans (Group 1) (Speit et al., 2007\& Fenech et al., 2016b).

Micronucleus test in exfoliated buccal cells is considered a tremendous non-invasive genotoxic biomarker that is approved by the Organization for Economic Co-operation and Development (OECD) (Majer et al., 2001; Holland et al., 2008).

Micronucleus (MN) refers to acentric chromosome remains or entire chromosomes that fail to join the mitotic spindle or unable to separate correctly to the descendant nuclei in anaphase. These fragments or entire chromosomes are then bordered by membrane and become micronuclei (Araldi et al., 2015\& Fenech et al., 2016a).

In fact, buccal epithelial cells (BECs) are considered a favored site for detection of initial changes brought by carcinogenic agents that enter the body through the nose or the mouth. This is because of their ability to metabolize contiguous carcinogens to reactive products. Moreover, collection of BECs is considered the minimally invasive technique for evaluation of DNA damage in humans compared with tissue biopsies or blood samples obtained for lymphocyte and erythrocyte analyses (Mr et al., 2014).

The current study aimed to examine duration of exposure as a determining factor of genotoxicity of formaldehyde exposure using micronucleus assay in exfoliated buccal epithelial cells (BEC). Also, correlate clinical manifestations of formaldehyde exposure with its genotoxic effects, and measure the formaldehyde air levels in dissecting rooms of Alexandria Faculty of Medicine, Egypt.

\section{Materials and Methods}

Subjects:

The study was conducted on randomly selected fifty volunteer subjects. They were divided according to duration of exposure to FA into; students group and staff members group. A prospective survey was carried out on the students group that included 40 first year undergraduate medical students. They were collected using systematic random sampling technique.

At the same time, a cross sectional survey was performed on 10 staff members of Human Anatomy and Embryology Department, Faculty of medicine, Alexandria University, Egypt, who attended the practical dissection lessons. All staff members, who shared in the practical anatomy lessons, at the Anatomy department were invited to contribute in the study. However, those who approved to participate in the research were 10 .

Subjects who had history of cancer, prior chemotherapy and/or radiotherapy, smoking, alcohol consumption, dietary factors especially vitamin deficiency or supplementation and radiographic examination in the last two weeks were excluded from the study.
Materials:

The materials used were; cotton swabs, test tube, centrifuge, incubator, light microscope (Olympus BX41) with oil lens coupled with digital camera (Olympus DP20) at medical research center of Alexandria Faculty of Medicine and MIRAN-IR gas analyzer that was provided by Occupational Health and Air pollution Research Centre, High Institution of Public Health, Alexandria university.

Micronucleus test was performed using chemicals that included; Phosphate buffer saline solution, 3:1 methanol and acetic acid as a fixative, deionized water, distilled water, ethanol $50 \%$ and $20 \%$, hydrochloric acid (HCL) 5moll (5M), schiff reagent, Light green stain $(0.2 \%)$ and emersion oil (cedar wood oil).

Methods:

The procedures followed in the current study were in accordance with the ethical standards on human experimentation. Ethical authorization was attained by the Ethics Committee of Alexandria Faculty of Medicine (IRB No: 00012098, FWA No: 00018699), Alexandria University. Informed consent was got from all subjects before participating in the research.

I. Self- administre questionnaire:

Each research subject was requested to fill in a pre-designed questionnaire to assess clinical signs and symptoms of exposure and to screen for exclusion criteria. It was an anonymous self-administered questionnaire that was designed and distributed by the authors of the research and it included questions about medical history, history of FA exposure such as duration of exposure and form of FA, protective and control measures such as using personal protective equipment (PPE), labeling of FA containers and using of material safety data sheet (MSDS).

Moreover, the questionnaire involved inquiries about symptoms related to exposure that included; skin symptoms such as rash and itching, eye symptoms such as burning, tearing, redness and blurring of vision, respiratory symptoms such as burning or dryness of nose, sore or burning throat, dyspnea, cough, chest tightness and inability to take deep breath and neurological symptoms such as headache, irritability or nervousness, lack of concentration, drowsiness and weakness or fatigue.

Before beginning the study, a pilot study was conducted to identify any potential methodological problems, on a randomly selected number of medical students and staff. This was done to evaluate reaction of study participants to the research procedures, data collection tools (sequence and clarity of questions and time needed to fill the questionnaire), sampling procedures and supervision and administration of field work activities. 
II. Micronucleus assay in exfoliated buccal epithelial cells (BEC):

For the students group, exfoliated buccal mucosal cells were collected twice. The first time was done before formaldehyde exposure (E0 group) and the second time was after one month of exposure (E1 group). While for the staff members group, buccal epithelial cells (BECs) were collected once.

Steps of micronucleus test:

After vigorous mouth washing with tap water, buccal epithelial cells (BECs) were collected by scraping the mucosal lining of the right and left cheeks using cotton swab moistened with phosphate buffer saline (Pastor et al., 2001\& Pastor et al., 2003).

Collected cells were moved to a swab tube inclosing $3 \mathrm{ml}$ phosphate buffer saline solution then to a test tube to undergo centrifugation in order to eliminate bacteria and cell debris which may confuse cell counting. Then the supernatant was discarded and the precipitant was diluted with phosphate buffer saline (Pastor et al., 2003). The resultant solution was then dropped on precleaned glass slides and dipped into a fixative solution of methanol and acetic acid (3:1) for about one minute. Then they were placed on hot plate for 10 minutes to dry (Kashyap and Reddy, 2012).

I. The dried slides were then stained using Feulgen technique and examined by the light microscope using oil immersion lens (1000x magnification) to count the frequency of micronucleated cells (MNCs). The frequency of micronuclei was determined by counting 1000 cell per subject for each sampling time. The slides were examined by two examiners to avoid interpersonal errors (Holland et al., 2008).

Feulgen staining procedure (Thomas et al., 2008):

Fixed slides were dipped sequentially for 1 minute each in $50 \%$ and $20 \%$ ethanol then washed for 2 minutes in deionized water. The slides then were immersed in 5M hydrochloric acid (HCL) for 30 minutes and then washed in running tap water for 30 seconds.

The slides were drained but not permitted to dry off before being immersed in Schiff's reagent at room temperature in the dark for 60 minutes. Slides were washed in running tap water for 30 seconds and rinsed well in deionized water for 1 minute.

Slides were stained for 20 seconds in $0.2 \%$ light green stain and rinsed well in deionized water for 2 minutes. Using light microscope, nuclei and micronuclei appear reddish purple in color while the cytoplasm appears green.

III. Measurement of air born level of formaldehyde (Elmarakby and Mansour, 2004\& Benigni et al., 2012):

In the present study, FA air born levels were measured twice in two different days in three dissecting rooms of Human Anatomy and Embryology Department, Alexandria Faculty of Medicine, Egypt using MIRAN-IR Gas Analyzer.
IV. Statistical analysis of the data (Hovhannisyan, 2010 \& Fenech et al., 2016a):

Data were fed to the computer and analyzed using IBM SPSS software package version 20.0. (Armonk, NY: IBM Corp) Qualitative data were described using number and percent. The KolmogorovSmirnov test was used to verify the normality of distribution. Quantitative data were described using ranges (minimum and maximum), mean, and standard deviations. Significance of the obtained results was judged at the $5 \%$ level.

The used tests were Chi-square test, Fisher's Exact or Monte Carlo, Student t-test, Kruskal Wallis test, Pearson coefficient, Mann Whitney test, Odds ratio (OR), Linear regression analysis and Receiver operating characteristic curve (ROC).

\section{Results}

Demographic data:

Age and sex

The present study was carried out on 50 subjects classified into 2 groups; students group (40 subjects; $57.5 \%$ of them were females and $42.5 \%$ were males) and staff members group (10 subjects $70 \%$ of them were females and $30 \%$ were males). The age of participants in the students group ranged from 18-20 years with a mean of $18.58 \pm 0.54$ years while the age of the subjects of staff members group ranged from 26-34 with a mean of $29.70 \pm 2.98$ years.

II. Medical history:

Table (1) shows a statistically significant difference between students and staff members groups according to allergy to chemicals and development of bronchitis where $\chi^{2}=21.383, \mathrm{p}<0.001$ and $\chi^{2}=8.220, \mathrm{p}=$ 0.022 respectively. Conversely, non-significant difference between both groups was observed according to hospital admission, regular medications and previous heart troubles. Formaldehyde exposure

1. Form of formaldehyde:

All of the participating subjects of the students group and $20 \%$ of the staff members group reported exposure to formaldehyde in gaseous form. Another 20\% of the staff members group declared exposure to FA in liquid form (formalin) and 60\% reported exposure to mixed forms of FA with significant difference between the three forms of FA where $\chi^{2}=30.268$ and $\mathrm{p}<0.001$. (Figure 1)

2. Daily exposure to formaldehyde

Regarding the daily exposure to $\mathrm{FA}$, it ranged from 1-2 hours/day with a mean of $1.45 \pm 0.49$ hours/day for the students group and 4-6 hours/day for the staff members group with a mean of $5.40 \pm 0.97$ hours/day. A statistically significant difference was detected between the two groups with $\mathrm{U}=0.00$ and $\mathrm{p}<0.001$. (Figure 2)

3. Total duration of exposure

The mean duration of exposure to FA in the students group was $2.03 \pm 0.42$ months while in the staff members group, it was $46.20 \pm 29.94$ months. A 
statistically significant difference between the two studied groups was demonstrated where $\mathrm{U}=0.0$ and $\mathrm{p}$ $<0.001$. (Figure 2)

Protection and control methods (Table 2)

The only used PPE by all participants in both studied groups was gloves. $80 \%$ of participants in the students group and all participants in the staff members group wore gloves during handling cadavers with FA. Moreover, all participants in the students group and $90 \%$ of those in the staff members group denied labeling of FA containers.

At the same time, all studied participants in both groups reported that they do not use material safety data sheet (MSDS). On the other hand, only $2.5 \%$ of participants in the students group and $10 \%$ of those in the staff members group have experienced spills of FA.

III. Symptoms related to FA exposure (Table 3)

\section{- Skin symptoms:}

Regarding skin problems, $87.5 \%$ of participants in the students group did not complain from skin problems upon exposure to FA. While $70 \%$ of those in the staff members group complained from rash and itching with significant difference between them where $\chi^{2}=14.501$ and $p=0.001 .70 \%$ of the staff members group who developed skin symptoms reported itching and the rest had skin rash.

\section{- Eye symptoms:}

Eye manifestations were recorded in all subjects of the staff members and $45 \%$ of the students group with a statistically significant difference where $\chi^{2}=9.821$ and $\mathrm{p}=0.001$. Burning and tearing were the main complaints each in $90 \%$ of the staff members group. Moreover, $70 \%$ complained from redness and $70 \%$ declared having blurring of vision.

\section{- Respiratory symptoms}

All studied participants of the staff members group and $57.5 \%$ of the students group complained from chest problems during exposure to FA with a significant difference between the two groups where $\chi^{2}=6.439$ and $\mathrm{p}=0.010$.

A statistically significant relation was noted between both groups regarding complaining from dyspnea during exposure to FA with $\chi^{2}=14.939$ and $\mathrm{p}=0.001$. Furthermore, during Anatomy classes, all participants in the staff members group and only $12.5 \%$ of those in the students group have reported complaining of cough with $\chi^{2}=29.167$ and $\mathrm{p}<0.001$.

\section{- Neurological manifestations:}

All participants of the staff members group and $60 \%$ of the students group reported neurological manifestations related to FA exposure with significant difference between them $\left(\chi^{2}=5.882, \mathrm{p}=0.020\right)$. Headache was reported in $25 \%$ of the students group and $90 \%$ of the staff members group with significant difference between the two groups where $\chi^{2}=14.346$ and $p<0.001$.

The majority of participants in the staff members group (80\%) but only $22.5 \%$ of the students group complained from weakness and fatigue with significant difference between the two studied groups $\left(\chi^{2}=11.787\right.$ and $\left.p=.001\right)$. At the same time, half of the staff members group (50\%) and $12.5 \%$ of the students group conveyed feeling drowsy upon exposure to FA where $\chi^{2}=7.031$ and $p=0.018$.

The present study demonstrated a significant positive correlation between total duration of exposure to FA (in months) and development of respiratory manifestations in the staff members group where $r=0.856$ and $\mathrm{p}=0.002$. (Table 4 )

Also, regarding total number of the studied subjects, there was significant positive correlation between total duration of exposure to FA (in months) and skin, eye, respiratory and neurological manifestations collectively where $(\mathrm{r}=0.584,0.517,0.797,0.393$ and $\mathrm{p}<0.001,<0.001,<0.001,0.005)$ respectively. (Table 4)

IV. Micronucleus test

Buccal epithelial cells smears stained by Feulgen light green technique showed buccal epithelial cells having pale green cytoplasm and reddish purple colored central nuclei. (Figure 3)

In the exposed subjects, some buccal epithelial cells enclosed micronuclei in addition to the central nucleus. The micronucleus was revealed by being reddish purple in color, in the same focal plane and the same texture of the nucleus, with no overlap with or bridge to the nucleus and its size is less than one third the diameter of the associated nucleus. (Figure 4)

The mean frequency of micronuclei in the studied groups; pre exposure (E0), after one month of exposure (E1) and staff members group were $(0.80 \pm$ 0.76/1000 cell), (1.05 $\pm 1.28 / 1000$ cell) and (2.60 \pm $1.26 / 1000$ cell) respectively with statistically significant difference between the three groups where $\mathrm{H}=14.227$ and $\mathrm{p}=0.001$. (Table 5)

Moreover, a non-significant difference was revealed between E0 and E1, regarding the frequency of $\mathrm{MN}$, where $\mathrm{p} 1=1.000$. On the other hand, staff members group showed statistically significant increase in frequency of $\mathrm{MN}$ than E0 and E1 where $\mathrm{p}_{2}=0.001$ and $\mathrm{p}_{3}=0.002$ respectively. (Table 5 )

In the current work, there was non-significant relation between MN frequency and sex distribution in each of the studied groups as well as in total number of the studied participants where $(\mathrm{t}=1.224,0.103,0.774$ and $\mathrm{p}=0.232,0.921,0.442$ ) respectively. (Table 6 )

However, there was a significant correlation between age and frequency of MN where $r=0.441$ and $\mathrm{p}=0.001$.

Regarding total number of studied subjects, there was a significant positive correlation between frequency of MN and daily duration of exposure to FA( in hours) and total duration of exposure (in months) where $\mathrm{r}=0.430, \mathrm{p}=0.002$ and $\mathrm{r}=0.416, \mathrm{p}=0.003$ respectively. (Table 7)

Moreover, the staff members group showed significant positive correlation between MN frequency 
and daily duration of exposure where $(\mathrm{r}=0.691$ and $\mathrm{P}=0.027$ ). (Table 7)

Table (8) shows significant positive correlation between eye manifestations and frequency of $\mathrm{MN}$ in the students group where $(\mathrm{r}=0.487$ and $\mathrm{p}=0.001)$.

Regarding total number of studied subjects, there was significant positive correlation between frequency of $\mathrm{MN}$ and skin, eye and respiratory symptoms where $(\mathrm{r}=0.294,0.611,0.298$ and $\mathrm{P}=0.005,<0.001$, 0.036) respectively. Oppositely, non-significant correlation was noted between $\mathrm{MN}$ frequency and neurological manifestations for the two studied groups as well as the total number of subjects where $(r=-0.096$, $0.191,0.157$ and $\mathrm{P}=0.554,0.597,0.275$ ) respectively. (Table 8)

Table (9) shows different regression equations for prediction of frequency of micronuclei using each of age, daily duration of exposure to FA (in hours) and total duration of exposure to FA (in months) as independent variables and $\mathrm{MN}$ frequency as dependent one with their estimation of reliability $\left(R^{2}\right)$, where the grater the value of $\mathrm{R}^{2}$, the higher the accuracy of the equation. Equation IV represents the highest significance using the three independent variables together to predict MN frequency.

Formaldehyde airborne levels

Using MIRAN-IR Gas Analyzer, the air born levels of FA were measured twice in three dissecting rooms in Human Anatomy and Embryology department, Alexandria University, Egypt. The resultant report was provided by Occupational Health and Air pollution Research Centre, High Institution of Public Health, Alexandria University.

It showed that in the first day the measured FA level in the room air was $1.63 \mathrm{ppm}$ and $2.44 \mathrm{ppm}$ in the anatomy lab 1 and 3 respectively while FA level was not detected in lab 2. In the second day, the FA level was $1.63 \mathrm{ppm}$ (in the room air), $9.77 \mathrm{ppm}$ (in the breathing zone of the students) and $13.84 \mathrm{ppm}$ (around the cadaver) in the anatomy lab 1, 2 and 3 respectively with a mean of the measured levels of FA in the two days collectively $5.86 \pm 5.62 \mathrm{ppm}$. Moreover, the permissible exposure level accepted by the Egyptian law is 0.3 ppm. (Table 10)

Table (1): Distribution of the studied subjects exposed to formaldehyde at Human Anatomy and Embryology Department, Alexandria Faculty of Medicine according to medical history.(n=50)

\begin{tabular}{|c|c|c|c|c|c|c|}
\hline \multirow[t]{2}{*}{ Medical history } & \multicolumn{2}{|c|}{ Students $(n=40)$} & \multicolumn{2}{|c|}{ Staff members $(n=10)$} & \multirow{2}{*}{$\chi^{2}$} & \multirow{2}{*}{$\mathbf{p}$} \\
\hline & No. & $\%$ & No. & $\%$ & & \\
\hline \multicolumn{7}{|l|}{ Hospital admission } \\
\hline No & 35 & 87.5 & 6 & 60.0 & \multirow{2}{*}{4.009} & ${ }^{\mathrm{FE}} \mathrm{p}=$ \\
\hline Yes & 5 & 12.5 & 4 & 40.0 & & 0.065 \\
\hline \multicolumn{7}{|l|}{ Regular medications } \\
\hline No & 35 & 87.5 & 8 & 80.0 & \multirow{2}{*}{0.374} & ${ }^{\mathrm{FE}} \mathrm{p}=$ \\
\hline Yes & 5 & 12.5 & 2 & 20.0 & & 0.616 \\
\hline \multicolumn{7}{|l|}{ Allergy to } \\
\hline No & 38 & 95.0 & 3 & 30.0 & \multirow{4}{*}{$21.383^{*}$} & \multirow{4}{*}{$\begin{array}{c}{ }_{\mathrm{MC}}^{\mathrm{MC}} \\
<0.001^{*}\end{array}$} \\
\hline Drugs & 0 & 0.0 & 1 & 10.0 & & \\
\hline Food & 2 & 5.0 & 2 & 20.0 & & \\
\hline Chemicals & 0 & 0.0 & 4 & 40.0 & & \\
\hline \multicolumn{7}{|l|}{ Respiratory problems } \\
\hline \multicolumn{7}{|l|}{ Asthma } \\
\hline No & 37 & 92.5 & 9 & 90.0 & \multirow{2}{*}{0.068} & \multirow{2}{*}{${ }^{\mathrm{FE}} \mathrm{p}=1.000$} \\
\hline Yes & 3 & 7.5 & 1 & 10.0 & & \\
\hline \multicolumn{7}{|l|}{ Emphysema } \\
\hline No & 40 & 100.0 & 10 & 100.0 & \multirow{2}{*}{-} & \multirow{2}{*}{-} \\
\hline Yes & 0 & 0.0 & 0 & 0.0 & & \\
\hline \multicolumn{7}{|l|}{ Bronchitis } \\
\hline No & 39 & 97.5 & 7 & 70.0 & \multirow{2}{*}{$8.220^{*}$} & \multirow{2}{*}{${ }^{\mathrm{FE}} \mathrm{p}=0.022^{*}$} \\
\hline Yes & 1 & 2.5 & 3 & 30.0 & & \\
\hline \multicolumn{7}{|l|}{ Sinusitis } \\
\hline No & 30 & 75.0 & 7 & 70.0 & \multirow{2}{*}{0.104} & \multirow{2}{*}{${ }^{\mathrm{FE}} \mathrm{p}=0.707$} \\
\hline Yes & 10 & 25.0 & 3 & 30.0 & & \\
\hline \multicolumn{7}{|l|}{ Heart attack or trouble } \\
\hline No & 40 & 100.0 & 10 & 100.0 & \multirow{2}{*}{ - } & \multirow{2}{*}{-} \\
\hline Yes & 0 & 0.0 & 0 & 0.0 & & \\
\hline
\end{tabular}

ఒ2: Chi square test, MC: Monte Carlo, FE: Fisher Exact, $p$ : $p$ value for comparing between the two groups

*: Statistically significant at $p \leq 0.05$ 
Table (2): Distribution of the exposure to formaldehyde among the studied participants at Human Anatomy and Embryology Department according to protection and control measures. $(n=50)$

\begin{tabular}{|c|c|c|c|c|c|c|}
\hline \multirow{2}{*}{ Protection and control measures } & \multicolumn{2}{|c|}{ Students $(n=40)$} & \multicolumn{2}{|c|}{ Staff members $(n=10)$} & \multirow{2}{*}{$\chi^{2}$} & \multirow[b]{2}{*}{$\mathbf{p}$} \\
\hline & No. & $\%$ & No. & $\%$ & & \\
\hline \multicolumn{7}{|l|}{ Personal protective equipment } \\
\hline Gloves & 32 & 80.0 & 10 & 100.0 & 2.381 & ${ }^{\mathrm{FE}} \mathrm{p}=0.184$ \\
\hline Respirator & 0 & 0.0 & 0 & 0.0 & - & - \\
\hline Goggles & 0 & 0.0 & 0 & 0.0 & - & - \\
\hline Glasses with side shields & 0 & 0.0 & 0 & 0.0 & - & - \\
\hline Others & 0 & 0.0 & 0 & 0.0 & - & - \\
\hline \multicolumn{7}{|l|}{ Labelling of containers } \\
\hline No & 40 & 100.0 & 9 & 90.0 & \multirow{2}{*}{4.082} & \multirow{2}{*}{${ }^{\mathrm{FE}} \mathrm{p}=0.200$} \\
\hline Yes & 0 & 0.0 & 1 & 10.0 & & \\
\hline \multicolumn{7}{|l|}{ Material safety } \\
\hline No & 40 & 100.0 & 10 & 100.0 & \multirow[b]{2}{*}{-} & \multirow{2}{*}{-} \\
\hline Yes & 0 & 0.0 & 0 & 0.0 & & \\
\hline \multicolumn{7}{|l|}{ Experience of spills } \\
\hline No & 39 & 97.5 & 9 & 90.0 & \multirow{2}{*}{1.172} & \multirow{2}{*}{${ }^{\mathrm{FE}} \mathrm{p}=0.363$} \\
\hline Yes & 1 & 2.5 & 1 & 10.0 & & \\
\hline
\end{tabular}

$\chi 2$ : Chi square test, FE: Fisher Exact, $p$ : $p$ value for comparing between the two groups, *: Statistically significant at $p \leq 0.05$

Table (3): Distribution of the exposure to formaldehyde among the studied participants at Human Anatomy and Embryology Department, according to symptoms related to FA exposure*. (n=50)

\begin{tabular}{|c|c|c|c|c|c|c|}
\hline \multirow{2}{*}{ Symptoms related to exposure } & \multicolumn{2}{|c|}{ Students $(n=40)$} & \multicolumn{2}{|c|}{ Staff members $(n=10)$} & \multirow[t]{2}{*}{$\chi^{2}$} & \multirow[t]{2}{*}{${ }^{E} \mathbf{p}$} \\
\hline & No. & $\%$ & No. & $\%$ & & \\
\hline \multicolumn{7}{|l|}{ Skin } \\
\hline No & 35 & 87.5 & 3 & 30.0 & \multirow{2}{*}{$14.501^{*}$} & \multirow{2}{*}{$0.001^{*}$} \\
\hline Yes & 5 & 12.5 & 7 & 70.0 & & \\
\hline Rash & 3 & 7.5 & 3 & 30.0 & 3.835 & 0.086 \\
\hline Itching & 3 & 7.5 & 7 & 70.0 & $19.531^{*}$ & $<0.001^{*}$ \\
\hline \multicolumn{7}{|l|}{ Eye } \\
\hline No & 22 & 55.0 & 0 & 0.0 & \multirow{2}{*}{$9.821^{*}$} & \multirow{2}{*}{$0.001^{*}$} \\
\hline Yes & 18 & 45.0 & 10 & 100.0 & & \\
\hline Burning & 14 & 35.0 & 9 & 90.0 & $9.742^{*}$ & $0.003^{*}$ \\
\hline Tearing & 6 & 15.0 & 9 & 90.0 & $21.429^{*}$ & $<0.001^{*}$ \\
\hline Redness & 1 & 2.5 & 7 & 70.0 & $27.121^{*}$ & $<0.001^{*}$ \\
\hline Blurring of vision & 5 & 12.5 & 7 & 70.0 & $14.501^{*}$ & $0.001^{*}$ \\
\hline \multicolumn{7}{|l|}{ Respiratory } \\
\hline No & 17 & 42.5 & 0 & 0.0 & \multirow{2}{*}{$6.439^{*}$} & \multirow{2}{*}{$0.010^{*}$} \\
\hline Yes & 23 & 57.5 & 10 & 100.0 & & \\
\hline Burning or dryness of nose & 11 & 27.5 & 9 & 90.0 & $13.021^{*}$ & $0.001^{*}$ \\
\hline Sore or burning throat & 4 & 10.0 & 10 & 100.0 & $32.143^{*}$ & $<0.001^{*}$ \\
\hline Dyspnea & 3 & 7.5 & 6 & 60.0 & $14.939^{*}$ & $0.001^{*}$ \\
\hline Cough & 5 & 12.5 & 10 & 100.0 & $29.167^{*}$ & $<0.001^{*}$ \\
\hline Chest tightness & 7 & 17.5 & 8 & 80.0 & $14.881^{*}$ & $<0.001^{*}$ \\
\hline Unable to take deep breath & 12 & 30.0 & 4 & 40.0 & 0.368 & 0.707 \\
\hline \multicolumn{7}{|l|}{ Neurological (Nervous) } \\
\hline No & 16 & 40.0 & 0 & 0.0 & \multirow{2}{*}{$5.882^{*}$} & \multirow{2}{*}{$0.020^{*}$} \\
\hline Yes & 24 & 60.0 & 10 & 100.0 & & \\
\hline Headache & 10 & 25.0 & 9 & 90.0 & $14.346^{*}$ & $<0.001^{*}$ \\
\hline Irritability or nervousness & 4 & 10.0 & 5 & 50.0 & $8.672^{*}$ & $0.010^{*}$ \\
\hline $\begin{array}{l}\text { Lack of concentration and problems in } \\
\text { remembering }\end{array}$ & 13 & 32.5 & 7 & 70.0 & 4.688 & 0.067 \\
\hline Drowsiness & 5 & 12.5 & 5 & 50.0 & $7.031^{*}$ & $0.018^{*}$ \\
\hline Weakness or fatigue & 9 & 22.5 & 8 & 80.0 & $11.787^{*}$ & $0.001^{*}$ \\
\hline
\end{tabular}

2: Chi square test, FE: Fisher Exact, $p: p$ value for comparing between the two groups

*: Statistically significant at $p \leq 0.05, *$ : Categories are not mutually exclusive 
Table (4): Correlation between symptoms related to FA exposure and total duration of exposure (in months) in the studied subjects exposed to formaldehyde (FA) at Human Anatomy and Embryology Department, Alexandria Faculty of Medicine. (n=50)

\begin{tabular}{|l|c|c|c|c|c|c|}
\hline & \multicolumn{6}{c|}{ Total duration of exposure (months) } \\
\hline \multicolumn{1}{|c|}{ Symptoms } & Students $(\mathbf{n}=\mathbf{4 0})$ & \multicolumn{2}{|c|}{ Staff members $(\mathbf{n}=\mathbf{1 0})$} & \multicolumn{2}{c|}{ Total subjects (n= 50) } \\
\hline & $\mathbf{r}$ & $\mathbf{p}$ & $\mathbf{r}$ & $\mathbf{p}$ & $\mathbf{r}$ & $\mathbf{P}$ \\
\hline Skin & -0.021 & 0.896 & 0.409 & 0.240 & $0.584^{*}$ & $<0.001^{*}$ \\
\hline Eye & -0.044 & 0.787 & -0.483 & 0.157 & $0.517^{*}$ & $<0.001^{*}$ \\
\hline Respiratory & 0.221 & 0.171 & $0.856^{*}$ & $0.002^{*}$ & $0.797^{*}$ & $<0.001^{*}$ \\
\hline Neurological (Nervous) & -0.146 & 0.369 & 0.200 & 0.580 & $0.393^{*}$ & $0.005^{*}$ \\
\hline Total symptoms & -0.001 & 0.994 & 0.180 & 0.618 & $0.703^{*}$ & $<0.001^{*}$ \\
\hline
\end{tabular}

$r$ : Pearson coefficient, *: Statistically significant at $p \leq 0.05$

Table (5): Comparison between the studied participants exposed to formaldehyde at Human Anatomy and Embryology Department, according to micronucleus (MN) frequency. (n=50)

\begin{tabular}{|c|c|c|c|c|c|c|c|c|}
\hline \multirow{3}{*}{$\begin{array}{l}\text { Micronucleus (MN) } \\
\text { frequency }\end{array}$} & \multicolumn{4}{|c|}{ Students $(n=40)$} & \multirow{2}{*}{\multicolumn{2}{|c|}{ Staff members $(n=10)$}} & \multirow{3}{*}{ Test of Sig. } & \multirow{3}{*}{$\mathbf{P}$} \\
\hline & \multicolumn{2}{|c|}{ (E0) } & \multicolumn{2}{|c|}{ (E1) } & & & & \\
\hline & No. & $\%$ & No. & $\%$ & No. & $\%$ & & \\
\hline 0 & 16 & 40.0 & 20 & 50.0 & 0 & 0.0 & \multirow{6}{*}{$\begin{array}{c}\chi^{2}= \\
27.945^{*}\end{array}$} & \multirow{6}{*}{$\begin{array}{r}{ }^{\mathrm{MC}} \mathrm{p} \\
<0.001\end{array}$} \\
\hline 1 & 16 & 40.0 & 7 & 17.5 & 2 & 20.0 & & \\
\hline 2 & 8 & 20.0 & 6 & 15.0 & 3 & 30.0 & & \\
\hline 3 & 0 & 0.0 & 5 & 12.5 & 3 & 30.0 & & \\
\hline 4 & 0 & 0.0 & 2 & 5.0 & 1 & 10.0 & & \\
\hline 5 & 0 & 0.0 & 0 & 0.0 & 1 & 10.0 & & \\
\hline Min. - Max. & \multicolumn{2}{|c|}{$0.0-2.0$} & \multicolumn{2}{|c|}{$0.0-4.0$} & \multicolumn{2}{|c|}{$1.0-5.0$} & $\mathrm{H}=$ & \multirow{2}{*}{$0.001^{*}$} \\
\hline Mean \pm SD. & 0.80 & 0.76 & & 28 & & & $14.227^{*}$ & \\
\hline $\begin{array}{c}\text { Significance between } \\
\text { groups }\end{array}$ & \multicolumn{8}{|c|}{$\mathrm{p}_{1}=1.000, \mathrm{p}_{2}=0.001^{*}, \mathrm{p}_{3}=0.002^{*}$} \\
\hline
\end{tabular}

$\chi^{2}$ : Chi square test, MC: Monte Carlo, $H$ : H for Kruskal Wallis test, Pairwise comparison bet. each 2 groups was done using Post Hoc Test (Dunn's for multiple comparisons test), $p$ : $p$ value for comparing between the three groups, $p 1: p$ value for comparing between E0 and E1, p2: $p$ value for comparing between E0 and Staff member, p3: $p$ value for comparing between E1 and Staff member, *: Statistically significant at $p \leq 0.05$, E0: pre exposure group, E1: 2 months after exposure

Table (6): Relation between micronucleus (MN) frequency and sex distribution in each studied group exposed to formaldehyde at Human Anatomy and Embryology Department. (n=50)

\begin{tabular}{|cc|c|c|c|}
\hline & \multicolumn{3}{|c|}{ Number of micronuclei } \\
\hline Sex & Students $(\mathbf{n}=\mathbf{4 0})$ & Staff members $(\mathbf{n}=\mathbf{1 0})$ & Total cases (n= 50) \\
\hline Male & $1.35 \pm 1.54$ & $2.67 \pm 2.08$ & $1.55 \pm 1.64$ \\
\hline Female & $0.83 \pm 1.03$ & $2.57 \pm 0.98$ & $1.23 \pm 1.25$ \\
\hline & $\mathbf{t}(\mathbf{p})$ & $1.224(0.232)$ & $0.103(0.921)$ & $0.774(0.442)$ \\
\hline
\end{tabular}

t: Student t-test

Table (7): Correlation between micronucleus (MN) frequency and age, total duration of exposure (in months) and daily exposure (in hours), of the studied groups exposed to formaldehyde at Human Anatomy and Embryology Department. $(n=50)$

\begin{tabular}{|l|c|c|c|c|c|c|}
\hline \multicolumn{1}{|c|}{ Studied parameter } & \multicolumn{9}{c|}{ Number of micronuclei } \\
\hline & Student $(\mathbf{n}=\mathbf{4 0})$ & \multicolumn{2}{c|}{ Staff member $(\mathbf{n}=\mathbf{1 0})$} & \multicolumn{2}{c|}{ Total cases $(\mathbf{n}=\mathbf{5 0})$} \\
\hline Age & $\mathbf{r}$ & $\mathbf{p}$ & $\mathbf{R}$ & $\mathbf{p}$ & $\mathbf{R}$ & $\mathbf{P}$ \\
\hline Total duration of exposure (months) & -0.099 & 0.544 & 0.230 & 0.523 & $0.441^{*}$ & $0.001^{*}$ \\
\hline Daily duration of exposure in hour & -0.099 & 0.544 & 0.261 & 0.467 & $0.416^{*}$ & $0.003^{*}$ \\
\hline
\end{tabular}

$r$ : Pearson coefficient,

*: Statistically significant at $p \leq 0.05$ 
Table (8): Correlation between micronucleus (MN) frequency and symptoms related to FA exposure of the studied groups exposed to formaldehyde at Human Anatomy and Embryology Department. (n=50)

\begin{tabular}{|l|c|c|c|c|c|c|}
\hline \multicolumn{1}{|c|}{ Symptoms } & \multicolumn{6}{c|}{ Micronucleus(MN) frequency } \\
\hline & \multicolumn{2}{|c|}{ Students (n = 40) } & \multicolumn{2}{c|}{ Staff members (n = 10) } & \multicolumn{2}{c|}{ Total subjects (n = 50) } \\
\hline Skin & $\mathbf{R}$ & $\mathbf{p}$ & $\mathbf{R}$ & $\mathbf{P}$ & $\mathbf{r}$ & $\mathbf{p}$ \\
\hline Eye & -0.108 & 0.507 & 0.323 & 0.363 & $0.294^{*}$ & $0.005^{*}$ \\
\hline Respiratory & $0.487^{*}$ & $0.001^{*}$ & 0.408 & 0.242 & $0.611^{*}$ & $<0.001^{*}$ \\
\hline Neurological (Nervous) & -0.260 & 0.105 & 0.477 & 0.163 & $0.298^{*}$ & $0.036^{*}$ \\
\hline Total symptoms & -0.096 & 0.554 & 0.191 & 0.597 & 0.157 & 0.275 \\
\hline
\end{tabular}

$r$ : Pearson coefficient, *: Statistically significant at $p \leq 0.05$

Table (9): Regression equations for prediction of MN frequency (X) from age, total duration of exposure (in months) and daily duration of exposure (in hours) in the studied subjects exposed to formaldehyde at Human Anatomy and Embryology Department. (n=50)

\begin{tabular}{|c|c|c|c|c|c|}
\hline No. & Equations & SE & $\mathbf{R}^{2}$ & B (95\% C.I) & $\mathbf{p}$ \\
\hline I & $\mathbf{X}=-1.392+$ Age $\mathrm{x} 0.132$ & 0.039 & 0.194 & $0.132(0.054-0.211)$ & $0.001^{*}$ \\
\hline II & $\mathrm{X}=1.070+$ Total duration of exposure (months) $\mathrm{x} 0.027$ & 0.008 & 0.173 & $0.027(0.010-0.044)$ & $0.003^{*}$ \\
\hline III & $\mathrm{X}=0.564$ + Daily exposure in hours $\mathrm{x} 0.355$ & 0.108 & 0.185 & $0.355(0.139-0.572)$ & $0.002^{*}$ \\
\hline \multirow[t]{3}{*}{ IV } & \multirow{3}{*}{$\begin{array}{l}X=-0.385+(\text { Age } \times 0.071)+(\text { total duration of exposure } \\
(\text { months }) \times 0.009)+(\text { Daily exposure in hours } x 0.077)\end{array}$} & \multirow[t]{3}{*}{1.229} & \multirow[t]{3}{*}{0.204} & $0.071(-0.143-0.284)$ & \multirow[t]{3}{*}{$0.014^{*}$} \\
\hline & & & & $0.009(-0.022-0.041)$ & \\
\hline & & & & $0.077(-0.514-0.669)$ & \\
\hline
\end{tabular}

R2: Coefficient of determination, B: Unstandardized Coefficients, (95\%C.I): 95\% confident interval, $t$ : $t$-test of significance, \#: All variables with $p<0.05$ was included in the multivariate, *: Statistically significant at $\mathrm{p} \leq 0.05$

Table (10): The air born levels of FA measured twice in three dissecting rooms at Human Anatomy and Embryology Department, Alexandria Faculty of Medicine.

\begin{tabular}{|c|c|c|}
\hline Measured lab & Formaldehyde level (ppm) & Formaldehyde level $\left(\mathrm{mg} / \mathrm{m}^{3}\right)$ \\
\hline \multicolumn{3}{|l|}{ Day 1} \\
\hline Anatomy lab 1 & 1.63 & 2 \\
\hline Anatomy lab 2 & Not detected & Not detected \\
\hline Anatomy lab 3 & 2.44 & 3 \\
\hline \multicolumn{3}{|l|}{ Day 2} \\
\hline Anatomy lab1 & 1.63 & 2 \\
\hline Anatomy lab2 ${ }^{\#}$ & 9.77 & 12 \\
\hline Anatomy lab3 ${ }^{\# \#}$ & 13.84 & 17 \\
\hline Min. - Max & $1.63-13.84$ & $2-17$ \\
\hline Mean \pm SD & $5.86 \pm 5.62$ & $7.2 \pm 6.9$ \\
\hline Permissible exposure level & $0.3 \mathrm{ppm}$ & $0.37 \mathrm{mg} / \mathrm{m}^{3}$ \\
\hline
\end{tabular}

The conversion equation is based on $25^{\circ} \mathrm{C}$ and 1 atmosphere:(23), $X \mathrm{ppm}=(\mathrm{Y} \mathrm{mg} / \mathrm{m3})(24.45) /$ (molecular weight), \#: in the breathing zone of the students, \#\#: around the cadaver 


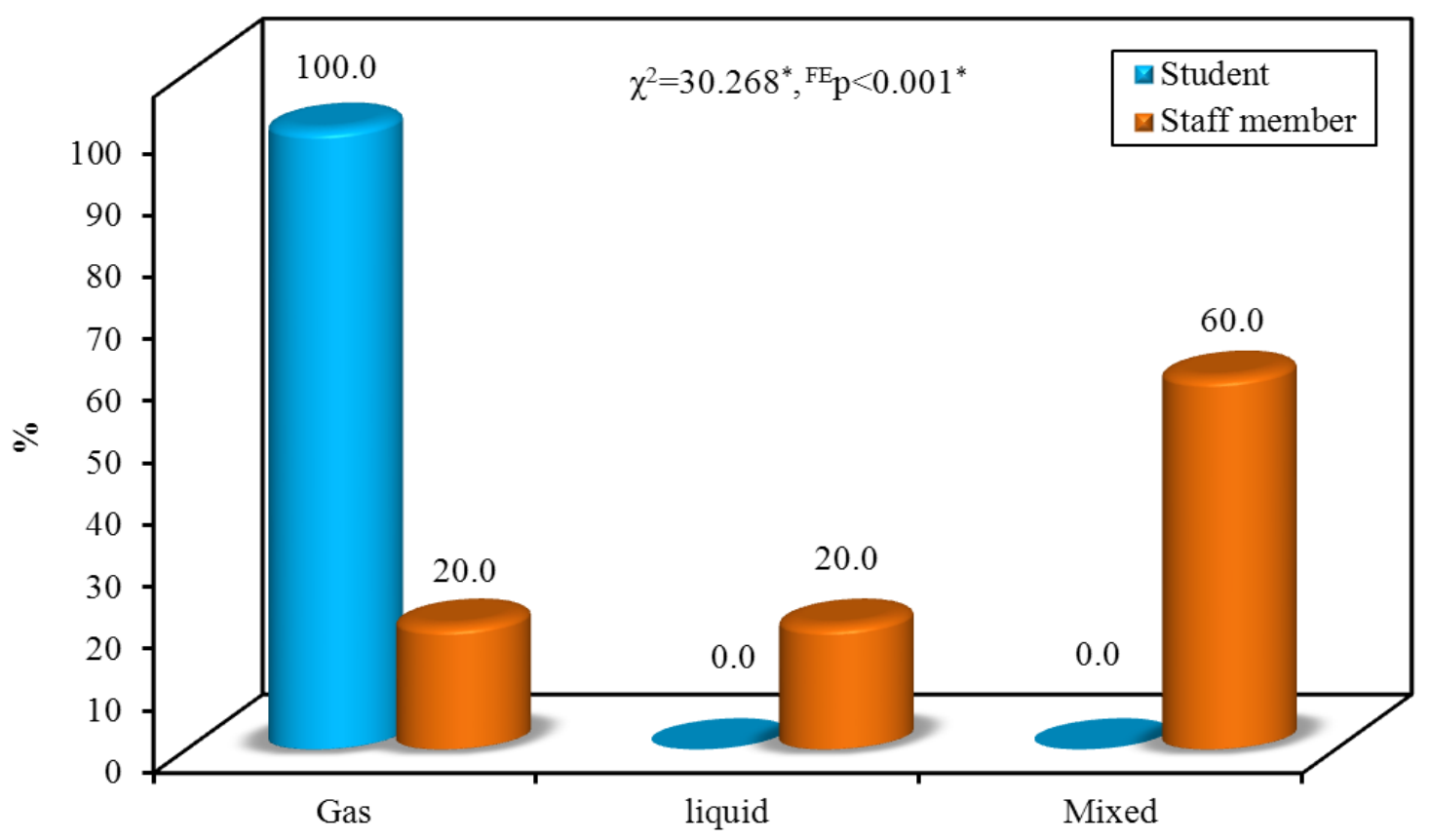

Figure (1): Distribution of the exposure to formaldehyde among studied participants at Human Anatomy and Embryology Department, according to Form formaldehyde (gas, liquid and mixed). (n=50)

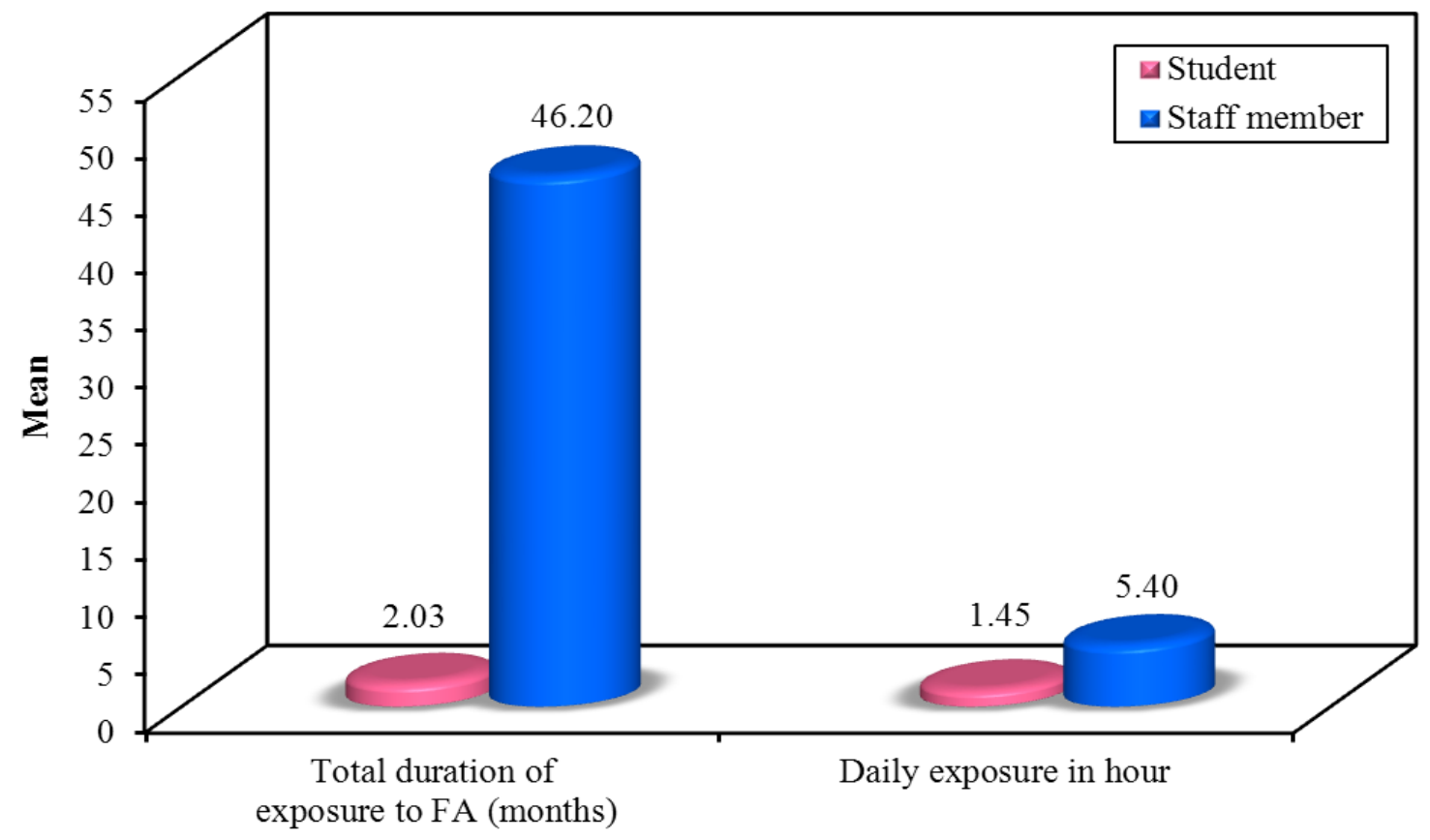

Figure (2): Distribution of the exposure to formaldehyde among studied participants at Human Anatomy and Embryology Department according to Total duration of exposure in months and Daily exposure in hour. (n=50) 

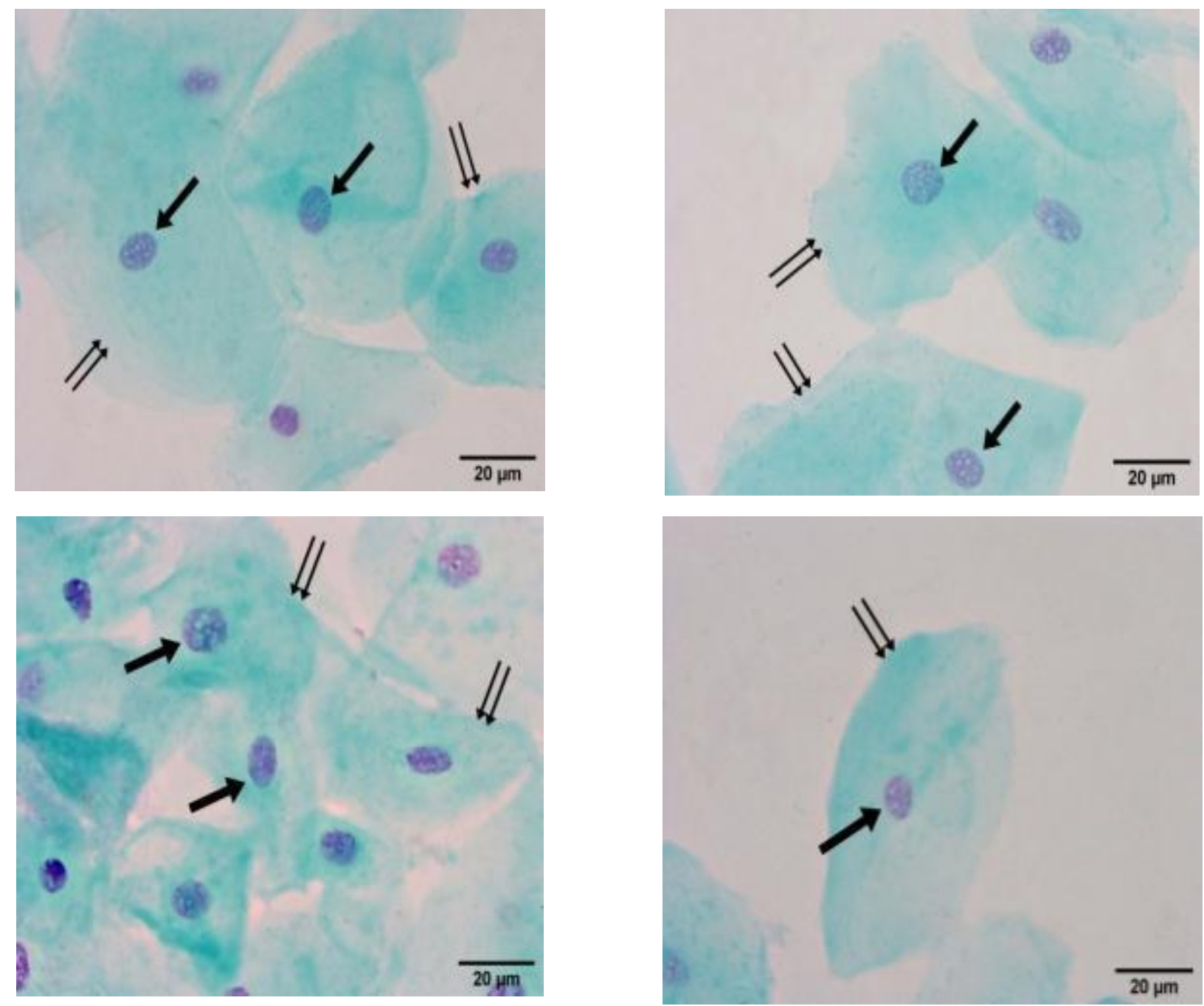

Figure (3): Photomicrographs of buccal smears from the pre-exposure group (EO), showing normal buccal epithelial cells (double thin arrows), with central nuclei (thick black arrows) surrounded by pale cytoplasm. (Feulgen light green stain, Mag. ×1000) 

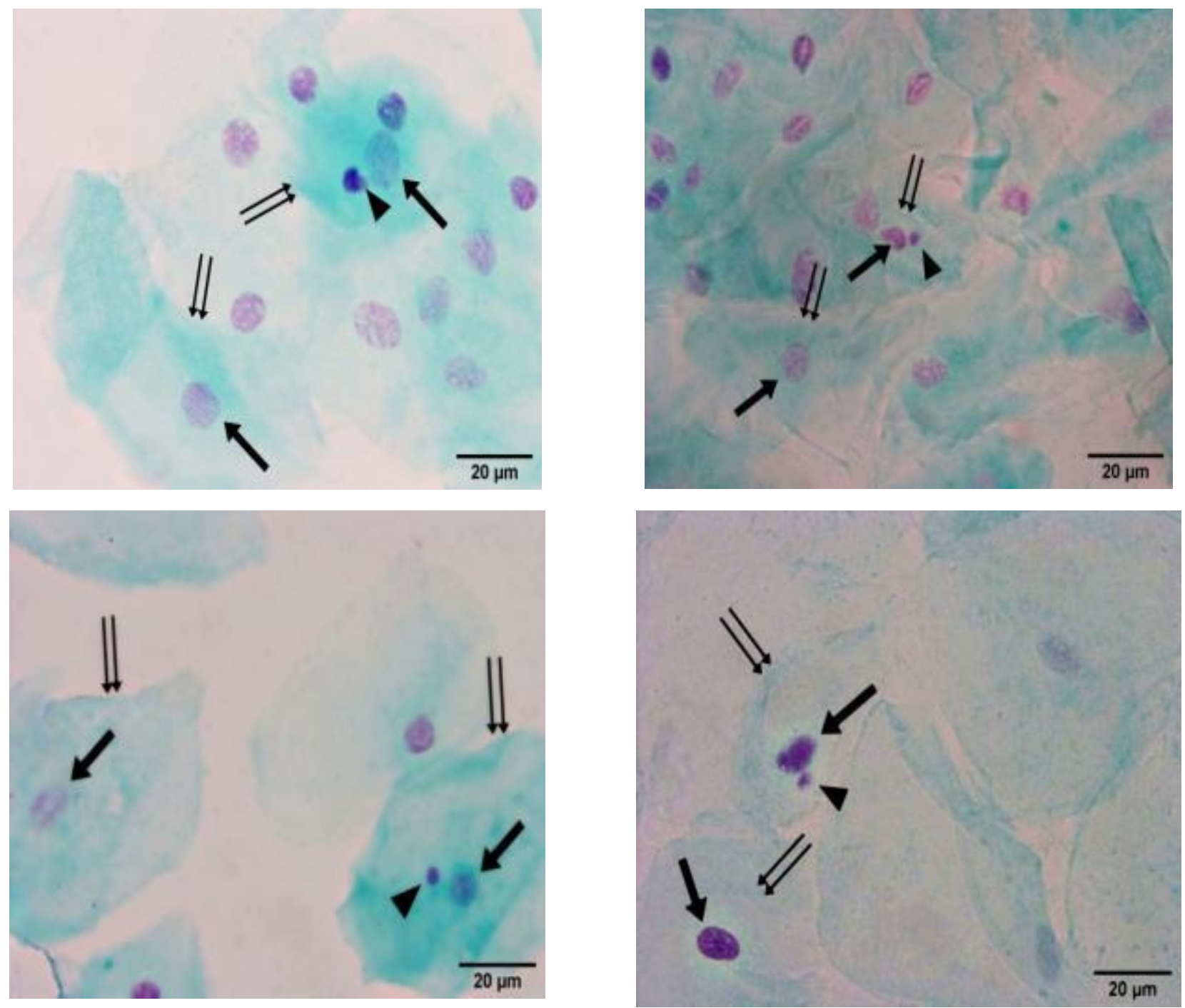

Figure (4): Photomicrographs of buccal smears of the exposed groups, showing buccal epithelial cells (double thin arrows), with central nuclei (thick black arrows) surrounded by pale cytoplasm. Micronuclei (arrow heads) are noticed in some cells.(Feulgen light green stain, Mag. $\times 1000)$

\section{Discussion}

Medical students, all through the dissection course, are exposed to formaldehyde whose exposure is considered to be one of the reasons of several chemical sensitivities (Nair et al., 2016).

The toxicity of formaldehyde depends on the route of exposure. Irritation occurs at the site of exposure, either through the nose, mouth or the skin. High amounts are cytotoxic and cause degeneration and necrosis of mucosal and epithelial cell layers (Kundu and Gangrade, 2015).

The current study designed to examine duration of exposure as a determining factor of genotoxicity of formaldehyde exposure using micronucleus assay in exfoliated buccal epithelial cells (BEC). Also, correlate clinical manifestations of formaldehyde exposure with its genotoxic effects, and measure the formaldehyde air levels in dissecting rooms of Alexandria Faculty of Medicine, Egypt.

In the current work, the age of participants ranged from 18-20 years in the students group and from 26-34 years in the staff members group with significant difference between the mean ages of both groups. This was matching to Lorenzoni et al (2017). On the other hand, it was contrary to Bouraoui et al (2013) who studied the genotoxic effects of FA on chronically exposed personnel with an age ranged between 27-54 years old. This may be due to different sample size included.

$57.5 \%$ of the students group, in the present study, were females and $42.5 \%$ were males, while in the 
staff members 'group $70 \%$ were females and 30\% were males. This was in agreement with Viegas et al (2010).

Regarding medical history and history of allergy in the current work, participants in the staff members group were significantly higher than those in the students group regarding allergy to chemicals. This was in agreement with Binawara (2010) who found that chronic exposure to formaldehyde was linked to immunological hypersensitivity as revealed by elevated circulating IgG and IgE autoantibodies to human serum albumin. On the other hand, Hisamitsu et al (2011) found that cadaver dissection related exposure did not result in any changes in the total level of IgE or the production of formaldehyde-specific IgE.

Also, in the present study, there was a significant difference between the studied groups regarding history of bronchitis. This was in agreement with Neghab et al (2011) who found that the rate of episodes of chest illness were significantly higher in subjects with chronic exposure to FA. It was explained by the fact that long term occupational exposure to FA resulted not only in acute partially reversible effects but also significant irreversible decrease in some parameters of pulmonary function such as vital capacity (VC) and Functional vital capacity (FVC) (Neghab et al., 2011).

Regarding the form of FA, in the current work, all of participants of the students group and $20 \%$ of those in the staff members group reported exposure to formaldehyde vapor. Another $20 \%$ of the staff members group exposed to formalin solution and $60 \%$ of them were exposed to mixed forms of FA. This may be attributed to the fact that staff members are more in contact with cadavers preserved with formalin. Kumaraswamy et al (2011) stated that formaldehyde gas evaporates from formalin solution and that toxic actions of FA can occur only after gaseous formaldehyde has become dissolved in water film of tissues.

In the current work, the mean duration of the daily exposure to FA was (1.45 \pm 0.49 hours) and (5.40 \pm 0.97 hours) for the students and staff members groups respectively with significant difference between them. Moreover, the mean of the total duration of exposure was (2.03 \pm 0.42 months) and $(46.20 \pm 29.94$ months) for the students and the staff members groups respectively. This was contrary to Lorenzoni et al (2017) who demonstrated that the students spent about 3.5 months (30-90 hours/semester) with a rate of one anatomy lesson weekly. This difference may be due to different curricular designs and number of anatomy classes (Lorenzoni et al., 2017).

It should be emphasized that using personal protective equipment is an essential measure to reduce the potential risk of exposure to formaldehyde in the place of work (Mirabelli et al., 2011). In the present study the single personal protective equipment worn by students and staff members groups was gloves. This was in agreement with Costa et al. (2015). This may be explained by the fact that wearing protective equipment other than gloves, like goggles and masks may impede the efficiency of activities performed, specifically taking notes and holding materials, and may cause communication difficulties. Hence, they were not preferred to be used by study participants.

Moreover, they might be unaware of the hazardous effects of FA. This was in agreement with Abdullahi (2014) who showed that 95\% of the respondents had no knowledge of the hazards and precautions to be taken against formaldehyde exposure as wearing protective equipment. Furthermore, unluckily, most of the students and laboratory assistants have slight or no knowledge about the carcinogenic effect of formaldehyde (Lang et al., 2008; Nair et al., 2016).

One of the most disturbing and troubled manifestations that appeared first, in the present work, were respiratory problems, where $57.5 \%$ of the students group and all participants of the staff members group suffered from them with significant difference between the two groups. It is in keeping with Wantke et al (2000) where inhalation of formaldehyde fumes caused minor irritation of the upper respiratory tract, shortness of breath, and decreased pulmonary function.

This observation was also in agreement with Tanaka et al (2003) where formaldehyde was considered a possible reason for nasopharyngeal tumors in humans, and this was the cause that the Japan Ministry of Education, Culture Sports, Science and Technology (MEXT) had put guidelines which suggested reducing use of gaseous formaldehyde in gross anatomy dissection rooms (Onyije and Avwioro, 2012\& Bharadwaja and Bafna, 2016).

Also, in the current work all of the subjects of the staff members group and $45 \%$ of the students group suffered from eye manifestations upon exposure to FA with significant difference between the two studied groups, which was consistent with Kundu and Gangrade (2015) who concluded that too much ocular exposure to FA could lead to reduced vision later in life. On the other hand, Wantke et al (2000) observed that the degree of eye redness varied according to increase of FA concentration while the duration of exposure had no effect on the amount of redness.

Formaldehyde may be present in the cerebrospinal fluid (CSF), as it can easily pass through the blood-brain barrier, and as a result, it would disturb neuroglial and nerve cells. Consequently, it is considered that exposure to high FA concentrations is a probable problem for medical students as well as professionals and workers at dissection rooms (Songur et al., 2010).

In the present study, all of the staff members group and $60 \%$ of the students group complained from neurological manifestations including headache, drowsiness and lack of concentration with significant difference between the two groups. This may be due to different duration of exposure to FA between the participants of the two studied groups. At the same time, FA has adverse effects on the central nervous system 
such as headaches, irritability, attention deficit, and impairment of memory and equilibrium. Consequently this affects assimilation throughout anatomy lessons because if a person is exhausted, dazed and feeling other symptoms like headache, slight or nothing would be grasped during dissection. (Kumaraswamy et al., 2011\& Onyije and Avwioro, 2012\& Bharadwaja and Bafna, 2016).

Regarding skin-related symptoms of FA exposure, in the present work, it had a low incidence among the students group (12.5\%) compared to the high incidence in the staff members group (70\%).This result was contrary to Kundu and Gangrade (2015) who found that skin manifestations were the least ranked effect of FA and this different results may be due to using different protective equipment by participants of both studies during dissection (Kundu and Gangrade, 2015).

In the present study, it was noticed that there was significant positive correlation between total duration of exposure to FA and the development of respiratory manifestations in the staff members group.

Moreover, there was significant positive correlation between total duration of FA exposure and skin, eye, respiratory and neurological manifestations in all participating subjects of the present work. This was in accordance with Wei et al (2007) who detected that symptoms caused by FA exposure depend on the period of time spent in the dissection room and recommended that decreasing duration of exposure could lead to decreased related symptoms.

However, this was contrary to the report of National Academy of Sciences (NAS) (2007) \&(Golden, 2011) which concluded that irritation due to FA does not follow Haber's law (concentration [c] $\times$ exposure time[t] $=$ response $[\mathrm{k}]$ ) for differentiation between short- and long-term levels of toxicity. In general, FA concentrations that do not cause short-term sensory irritation also would not cause sensory irritation after repetitive exposures. This means that, for formaldehydeinduced sensory irritation, there are no significant differences between short and longer periods of exposure. However, this is applicable only on sensory irritation and not on tissue-damaging events like cytotoxicity caused by exposure to greater concentrations (Shusterman et al., 2006; Golden, 2011).

In the current study, the mean frequency of MN in the students group after one month of exposure to FA (E1) was $1.05 \pm 1.28 / 1000$ cell while in the staff members group was $2.60 \pm 1.26 / 1000$ cell. This results coincided with Speit et al. (2007). However, Ladeira et al. (2011) and Lorenzoni et al. (2017) showed lower frequencies of $\mathrm{MN}$. This may be due to different sample size, exclusion criteria and different staining techniques.

Moreover, non-significant difference was noted between E0 (pre exposure group) and E1 (after one month of exposure). On the other hand, staff members group showed statistically significant increase in frequency of $\mathrm{MN}$ than E0 and E1 respectively.
In the current work, there was a significant correlation between age and frequency of MN. This was in agreement with Nefić et al (2013) in which they concluded that micronucleus and other cytogenetic marker's frequencies tended to be greater in older subjects than in younger ones. This may be explained by the fact that aging in humans is linked to many gross cellular changes, including changed size and morphology, genomic unsteadiness with decreased efficiency of DNA repair and alterations in expression and proliferation. Consequently, it was considered that a greater $\mathrm{MN}$ rate is directly linked to diminished efficacy of DNA repair and greater instability of the genomic (Orsière et al., 2006 \& Zietkiewicz et al., 2009 \& Ladeira et al., 2011\& Bernstein et al., 2012).

On the other hand, non-significant relation was observed between frequency of MN and sex distribution in the studied groups of the present study. This result was contrary to Khlifi et al (2013). This may be explained as the greater MN frequency in females could be caused by the bigger tendency of the $\mathrm{X}$ chromosome to be fragmented and enclosed within micronucleus in relation to other chromosomes. Also, females have duplicated number of the chromosome in comparison to only one in males (Fenech and Bonassi, 2011\& Khlifi et al., 2013).

Furthermore, significant positive correlation was noted in the current work between duration daily exposure to FA and frequency of MN. This was in accordance with Ye et al (2005).

In fact, exposure duration is considered an important factor for initiation of tissue destructive actions like cytotoxicity and genotoxicity after exposure to high levels of FA. This may be due to a cumulative effect which increases occupational risks in long-term exposed individuals (Golden, 2011).

Another confounding factor is the staining technique. DNA particular stains are favored for staining nuclei, micronuclei, and other abnormalities of nuclei in exfoliated cells of buccal mucosa. In the current work, Feulgen staining technique was used, because of it is DNA specific and the cytoplasm will appear clear and transparent which allows easy identification of micronuclei (Holland et al., 2008\& Lorenzoni et al., 2017).

On the other hand, using DNA non-specific stains as geimsa stain in buccal exfoliated cells is associated with false positive results due to cellular structures resembling micronucleus that could be stained, such as keratohyalin granules or bacteria and by mistake counted as MN (Lorenzoni et al., 2017).

Furthermore, many studies that applied MN test in exfoliated cells concluded several advantages in comparison to other genotoxicity tests that are presently applied for human biomonitoring (Majer et al., 2001\& Viegas et al., 2010\& Bolognesi et al., 2015).

First, is the simplicity and rapidity of the test. In MN assay, cells can be collected simply and need no cultivation. Handling and staining of the cells take less 
time in comparison to other tests and can be accomplished in laboratories with simple equipment (Majer et al., 2001; Bolognesi et al., 2015).

Also, the cells could be fixed and stored for lengthy times. Moreover, unlike most structural chromosomal aberrations (CA), as sister chromatid exchange (SCE), MN are detected in the interphase of cell cycle. Consequently, samples mostly comprise an adequately high amount of countable cells (Majer et al., 2001).

Moreover, the easy way of sample collection with non-invasive methods makes the test applicable to large sample sizes (Majer et al., 2001\& Pastor et al., 2001).

In addition, the frequency of $\mathrm{MN}$ in buccal cells was demonstrated to be a predictive indicator for diseases and cancer of the mouth and appears to be a worthy method for biomonitoring of mouth cancer (Bonassi et al., 2001; Majer et al., 2001).

In the present study, three significant regression equations for determination of frequency of $\mathrm{MN}$ were developed using age, total duration of FA exposure in months and daily duration of FA exposure (in hours). The most accurate equation was equation IV using the three independent variables together to predict $\mathrm{MN}$ frequency. Consequently, increased number of variables in the same regression analysis (mutable regression analysis) is associated with higher accuracy for prediction of the dependent variable (Cohen et al., 2002).

On the other hand, the mean value of airborne FA levels, in the current work, was $5.86 \pm 5.62$ ppm measured by MIRAN-IR Gas Analyzer in three dissecting rooms, in two different days in Human Anatomy and Embryology department, Alexandria University, Egypt, which is far above the OSHA recommendations (the permissible exposure level (PEL) of FA in the work place is $0.75 \mathrm{ppm}$ measured as an 8hour time- weighted average and $2 \mathrm{ppm}$ in a 15-minute exposure period). Also, these FA levels are higher than the accepted level by the Egyptian law which is $0.3 \mathrm{ppm}$ (Gabard et al., 2012; Kashyap and Reddy, 2012).

During measurement, FA level could not be detected in anatomy lab two in day one due to lake of specimens on the benches in that day in contrast to higher FA levels in day two measurements that could be attributed to the fact that the anatomy lab was full of cadaver specimens for practical revision for the students. At the same time, the airborne level of FA in lab two in that day was less than the minimum absorbance level of FA by MIRAN-IR Gas Analyzer (Błaszczyk and Mielzynska-Svach, 2014).

However, it was noticed that higher FA concentrations were measured in the breathing zone of the students and around the cadaver on the benches. This was in agreement with Sheta et al (2015) and may be explained by the fact that the closer the distance to the source of FA emission the higher the level of exposure.
These levels were in agreement with Costa et al. (2015) who found that the students and professionals studied in Anatomy and Pathology laboratories are exposed to levels of FA higher than both national and international permissible air standards and guidelines.

On the other hand, Vimercati et al (2010) measured lower mean values of FA airborne levels in Pathologic anatomy laboratories. This may be due to the presence of good ventilation systems in dissection rooms. Moreover, workers used to turn off air conditioners and open windows after ending of their work shift to ensure natural ventilation. Furthermore, use of different techniques of air sampling and analysis, may give different results of FA level measurements (Vimercati et al., 2010).

In their study, Ohmichi et al (2006) concluded that indoor concentrations of formaldehyde may depend on the contents and dimensions of dissection hall and appears to be greater during dissection of body cavities or deep structures.

Ladeira et al (2011) stated that prevention has to be a priority in safety measures for those who accomplish dissection of cadavers. Generally, decreasing FA exposure in this occupation setting may be performed through sufficient ventilation of local exhaust and putting biological specimens in closed containers while performing the macroscopic examination.

\section{Conclusion}

The data obtained from the present study showed that the population studied is exposed to high concentrations of formaldehyde above the standard levels according to time of exposure. Age might be a confounding factor in the current work. Exposure to high concentrations of FA is an important factor for the development of clinical irritating manifestations, with positive correlation with $\mathrm{MN}$ frequency. However, prolonged duration of exposure is the main factor for the development of Formaldehyde induced genotoxicity.

\section{Recommendations}

Based on the findings of the present study, the following recommendations are proposed:

- Medical professionals and students, in Alexandria Faculty of Medicine, should be alert about the probable adverse health effects of formaldehyde inhalation.

- Inspection of PPE including gloves, goggles, lab coats and masks for both students and staff members should be done.

- It is important to adjust the schedule of anatomy classes in order to decrease the working hours for the anatomy staff members.

- The Anatomy dissection halls should be supported with adequate ventilation systems including air conditioners and air purifiers such as charcoal filters and photocatalytic oxidations techniques with frequent monitoring of FA air born levels and ventilation equipment. Moreover, windows should be 
kept opened early in the morning before the people enter the rooms and at the end of the day to maintain natural ventilation of the dissection halls.

\section{References}

Abdullahi M., Zagga, A. D., Iseh, K. R., Amutta, S. B., Aliyu, D. (2014): Nasal response from Formaldehyde exposure used as cadaver preservative among pre-clinical medical students in a Nigerian medical college. International Journal of Otolaryngology and Head \& Neck Surgery. 3(4): 173-178.

Araldi R. P., de Melo, T. C., Mendes, T. B., de Sá Júnior, P. L., Nozima, B. H., Ito, E. T., de Carvalho, R. F., de Souza, E. B., de Cassia Stocco, R. (2015): Using the comet and micronucleus assays for genotoxicity studies: A review. Biomedicine \& pharmacotherapy = Biomedecine \& pharmacotherapie. 72: 74-82.

Benigni R., Bossa, C., Tcheremenskaia, O., Battistelli, C. L., Crettaz, P. (2012): The new ISSMIC database on in vivo micronucleus and its role in assessing genotoxicity testing strategies. Mutagenesis. 27(1): 87-92.

Bernstein C., Prasad, A. R., Nfonsam, V. (2012). DNA Damage, DNA Repair and Cancer. In C. Chen (Ed.), New Research Directions in DNA Repair. Croatia: IntechOpen.

Bharadwaja A., Bafna, G. (2016): Harmful effects of formalin on first MBBS students: a questionnaire study. Journal of Evolution of Medical and Dental Sciences. 5(56): 3823-3826.

Binawara B. K., Rajnee, C. S., Mathur, K., Sharma, H., Goyal, K. (2010): Acute effect of formalin on pulmonary function tests in medical students. Pakistan Journal of Physiology. 6(2): 8-10.

Błaszczyk E., Mielzynska-Svach, D. (2014): Micronucleus assay in epithelial cells from the oral cavity and urinary tract in female smokers and non-smokers. Environmental Biotechnology. 10(2): 60-65.

Bolognesi C., Bonassi, S., Knasmueller, S., Fenech, M., Bruzzone, M., Lando, C., Ceppi, M. (2015): Clinical application of micronucleus test in exfoliated buccal cells: A systematic review and metanalysis. Mutation research. Reviews in mutation research. 766: 20-31.

Bonassi S., Neri, M., Puntoni, R. (2001): Validation of biomarkers as early predictors of disease. Mutation research. 480-481: 349-358.

Bouraoui S., Mougou, S., Brahem, A., Tabka, F., Ben Khelifa, H., Harrabi, I., Mrizek, N., Elghezal, H., Saad, A. (2013): A combination of micronucleus assay and fluorescence in situ hybridization analysis to evaluate the genotoxicity of formaldehyde. Archives of environmental contamination and toxicology. 64(2): 337-344.
Cohen J., Cohen, P., West, S. G., Aiken, L. S. (2002). Introduction. In J. Cohen, P. Cohen, S. G. West \& L. S. Aiken (Eds.), Applied multiple regression/correlation analysis for the behavioral sciences (3rd ed p.p. 1-18). UK: Routledge.

Costa S., Carvalho, S., Costa, C., Coelho, P., Silva, S., Santos, L. S., Gaspar, J. F., Porto, B., Laffon, B., Teixeira, J. P. (2015): Increased levels of chromosomal aberrations and DNA damage in a group of workers exposed to formaldehyde. Mutagenesis. 30(4): 463-473.

da Costa S. C. B. (2014): Occupational exposure to formaldehyde-genotoxic damage and susceptibility evaluation in anatomical pathology laboratory workers. Avialable from: https://repositorio-

aberto.up.pt/bitstream/10216/72447/2/30954.pdf [Accessed on: Jan, 2019].

Elmarakby F. A., Mansour, T. A. (2004): VOCsenrichment factor as an indicator of IAQ and health problems in economic residences in Alexandria. Journal of High Institute of Public Health. 34(1): 225-244.

Fenech M., Bonassi, S. (2011): The effect of age, gender, diet and lifestyle on DNA damage measured using micronucleus frequency in human peripheral blood lymphocytes. Mutagenesis. 26(1): 43-49.

Fenech M., Knasmueller, S., Bolognesi, C., Bonassi, S., Holland, N., Migliore, L., Palitti, F., Natarajan, A. T., Kirsch-Volders, M. (2016a): Molecular mechanisms by which in vivo exposure to exogenous chemical genotoxic agents can lead to micronucleus formation in lymphocytes in vivo and ex vivo in humans. Mutation research. 770(Pt A): 12-25.

Fenech M., Nersesyan, A., Knasmueller, S. (2016b): A systematic review of the association between occupational exposure to formaldehyde and effects on chromosomal DNA damage measured using the cytokinesis-block micronucleus assay in lymphocytes. Mutation research. 770(Pt A): 46-57.

Gabard D. L., Lowe, D. L., Chang, J. W. (2012): Current and future instructional methods and influencing factors in anatomy instruction in physical therapy and medical schools in the U.S. Journal of allied health. 41(2): 53-62.

Golden R. (2011): Identifying an indoor air exposure limit for formaldehyde considering both irritation and cancer hazards. Critical reviews in toxicology. 41(8): 672-721.

Hisamitsu M., Okamoto, Y., Chazono, H., Yonekura, S., Sakurai, D., Horiguchi, S., Hanazawa, T., Terada, N., Konno, A., Matsuno, Y., Todaka, E., Mori, C. (2011): The influence of environmental exposure to formaldehyde in nasal mucosa of 
medical students during cadaver dissection. Allergology international : official journal of the Japanese Society of Allergology. 60(3): 373379.

Holland N., Bolognesi, C., Kirsch-Volders, M., Bonassi, S., Zeiger, E., Knasmueller, S., Fenech, M. (2008): The micronucleus assay in human buccal cells as a tool for biomonitoring DNA damage: the HUMN project perspective on current status and knowledge gaps. Mutation research. 659(1-2): 93-108.

Hovhannisyan G. G. (2010): Fluorescence in situ hybridization in combination with the comet assay and micronucleus test in genetic toxicology. Molecular cytogenetics. 3: 17-17.

Kashyap B., Reddy, P. S. (2012): Micronuclei assay of exfoliated oral buccal cells: means to assess the nuclear abnormalities in different diseases. Journal of cancer research and therapeutics. 8(2): 184-191.

Khlifi R., Trabelsi-Ksibi, F., Chakroun, A., Rebai, A., Hamza-Chaffai, A. (2013): Cytogenetic abnormality in exfoliated cells of buccal mucosa in head and neck cancer patients in the Tunisian population: impact of different exposure sources. BioMed research international. 2013: 905252.

Kim K. H., Jahan, S. A., Lee, J. T. (2011): Exposure to formaldehyde and its potential human health hazards. Journal of environmental science and health. Part C, Environmental carcinogenesis \& ecotoxicology reviews. 29(4): 277-299.

Kumaraswamy J., Hirusappa, R., Naidu, J., Raghavendra, R. (2011): A silent killer in the laboratory Formaldehyde: Review of effects and management. International Journal of Oral and Maxillofacial Pathology. 2(2): 13-19.

Kundu S., Gangrade, P. (2015): Study of the toxic effects of formaldehyde vapours within dissection hall on the first year Indian medical students. International Journal of Anatomy and Research. 3(2): 1179-1190.

Ladeira C., Viegas, S., Carolino, E., Prista, J., Gomes, M. C., Brito, M. (2011): Genotoxicity biomarkers in occupational exposure to formaldehyde--the case of histopathology laboratories. Mutation research. 721(1): 15-20.

Lang I., Bruckner, T., Triebig, G. (2008): Formaldehyde and chemosensory irritation in humans: a controlled human exposure study. Regulatory toxicology and pharmacology : RTP. 50(1): 2336.

Lorenzoni D. C., Pinheiro, L. P., Nascimento, H. S., Menegardo, C. S., Silva, R. G., Bautz, W. G., Henriques, J. F., Almeida-Coburn, K. L., da Gama-de-Souza, L. N. (2017): Could formaldehyde induce mutagenic and cytotoxic effects in buccal epithelial cells during anatomy classes? Medicina oral, patologia oral y cirugia bucal. 22(1): e58-e63.

Majer B. J., Laky, B., Knasmüller, S., Kassie, F. (2001): Use of the micronucleus assay with exfoliated epithelial cells as a biomarker for monitoring individuals at elevated risk of genetic damage and in chemoprevention trials. Mutation research. 489(2-3): 147-172.

Mirabelli M. C., Holt, S. M., Cope, J. M. (2011): Anatomy laboratory instruction and occupational exposure to formaldehyde. Occupational and environmental medicine. 68(5): 375-378.

Mr P., Guruprasad, Y., Jose, M., Saxena, K., K, D., Prabhu, V. (2014): Comparative Study of Genotoxicity in Different Tobacco Related Habits using Micronucleus Assay in Exfoliated Buccal Epithelial Cells. J Clin Diagn Res. 8(5): ZC21-ZC24.

Nair S. K., Thaduri, N., Joshi, R. V., Gupta, S. D. (2016): An exploration of hazardous effects of formaldehyde fumes on medical students. International Journal of Biomedical and Advance Research. 7(9): 485-488.

Nefić H., Musanovic, J., Kurteshi, K., Prutina, E., Turcalo, E. (2013): The effects of sex, age and cigarette smoking on micronucleus and degenerative nuclear alteration frequencies in human buccal cells of healthy Bosnian subjects. Journal of Health Sciences. 3(3): 196-204.

Neghab M., Soltanzadeh, A., Choobineh, A. (2011): Respiratory morbidity induced by occupational inhalation exposure to formaldehyde. Industrial health. 49(1): 89-94.

Nielsen G. D., Larsen, S. T., Wolkoff, P. (2013): Recent trend in risk assessment of formaldehyde exposures from indoor air. Archives of toxicology. 87(1): 73-98.

Ohmichi K., Komiyama, M., Matsuno, Y., Takanashi, Y., Miyamoto, H., Kadota, T., Maekawa, M., Toyama, Y., Tatsugi, Y., Kohno, T. (2006): Formaldehyde exposure in a gross anatomy laboratory. Personal exposure level is higher than indoor concentration (5 pp). Environmental Science and Pollution Research. 13(2): 120-124.

Onyije F. M., Avwioro, O. G. (2012): Excruciating effect of formaldehyde exposure to students in gross anatomy dissection laboratory. The international journal of occupational and environmental medicine. 3(2): 92-95.

Orsière T., Sari-Minodier, I., Iarmarcovai, G., Botta, A. (2006): Genotoxic risk assessment of pathology and anatomy laboratory workers exposed to formaldehyde by use of personal air sampling and analysis of DNA damage in peripheral lymphocytes. Mutation research. 605(1-2): 3041. 
Pastor S., Creus, A., Parrón, T., Cebulska-Wasilewska, A., Siffel, C., Piperakis, S., Marcos, R. (2003): Biomonitoring of four European populations occupationally exposed to pesticides: use of micronuclei as biomarkers. Mutagenesis. 18(3): 249-258.

Pastor S., Gutiérrez, S., Creus, A., Xamena, N., Piperakis, S., Marcos, R. (2001): Cytogenetic analysis of Greek farmers using the micronucleus assay in peripheral lymphocytes and buccal cells. Mutagenesis. 16(6): 539-545.

Sheta S. S., Zalat, M. M., Alazizi, N. M., El-Sebaey, A., Ibrahim, O. Y., Abdul Rahman, M. M. (2015): 1 Genotoxicity biomarkers among formaldehyde exposed subjects in anatomy \&amp; embryology departments, faculty of medicine zagazig university. Egyptian Journal of Occupational Medicine. 39(1): 1-17.

Shusterman D., Matovinovic, E., Salmon, A. (2006): Does Haber's law apply to human sensory irritation? Inhalation Toxicology. 18(7): 457471.

Songur A., Ozen, O. A., Sarsilmaz, M. (2010). The Toxic Effects of Formaldehyde on the Nervous System In D. M. Whitacre (Ed.), Reviews of Environmental Contamination and Toxicology (p.p. 105-118). New York, NY: Springer New York.

Speit G., Schmid, O., Fröhler-Keller, M., Lang, I., Triebig, G. (2007): Assessment of local genotoxic effects of formaldehyde in humans measured by the micronucleus test with exfoliated buccal mucosa cells. Mutation Research/Genetic Toxicology and Environmental Mutagenesis. 627(2): 129-135.

Tanaka K., Nishiyama, K., Yaginuma, H., Sasaki, A., Maeda, T., Kaneko, S. Y., Onami, T., Tanaka, M. (2003): Formaldehyde exposure levels and exposure control measures during an anatomy dissecting course. Kaibogaku zasshi. Journal of anatomy. 78(2): 43-51.

Thomas P., Harvey, S., Gruner, T., Fenech, M. (2008): The buccal cytome and micronucleus frequency is substantially altered in Down's syndrome and normal ageing compared to young healthy controls. Mutation research. 638(1-2): 37-47.

Viegas S., Ladeira, C., Nunes, C., Malta-Vacas, J., Gomes, M., Brito, M., Mendonca, P., Prista, J. (2010): Genotoxic effects in occupational exposure to formaldehyde: A study in anatomy and pathology laboratories and formaldehyderesins production. Journal of occupational medicine and toxicology (London, England). 5(1): 25.

Vimercati L., Carrus, A., Martino, T., Galise, I., Minunni, V., Caputo, F., Dell'erba, A., Assennato, G. (2010): Formaldehyde exposure and irritative effects on medical examiners, pathologic anatomy post-graduate students and technicians. Iranian journal of public health. 39(4): 26-34.

Wantke F., Focke, M., Hemmer, W., Bracun, R., WolfAbdolvahab, S., Götz, M., Jarisch, R., Götz, M., Tschabitscher, M., Gann, M., Tappler, P. (2000): Exposure to formaldehyde and phenol during an anatomy dissecting course: sensitizing potency of formaldehyde in medical students. Allergy. 55(1): 84-87.

Wei C. N., Haradal, K., Ohmori, S., Wef, Q. J., Minamoto, K., Veda, A. (2007): Subjective symptoms of medical students exposed to formaldehyde during a gross anatomy dissection course. International Journal of Immunopathology and Pharmacology. 20(S2): 23-25.

Ye X., Yan, W., Xie, H., Zhao, M., Ying, C. (2005): Cytogenetic analysis of nasal mucosa cells and lymphocytes from high-level long-term formaldehyde exposed workers and low-level short-term exposed waiters. Mutation research. 588(1): 22-27.

Zietkiewicz E., Wojda, A., Witt, M. (2009): Cytogenetic perspective of ageing and longevity in men and women. Journal of applied genetics. 50(3): 261273. 


\section{هل مدة التعرض عامل محدد للسمية الجينية والمظاهر السريرية التي يسبيها الفورمالديهايد؟}

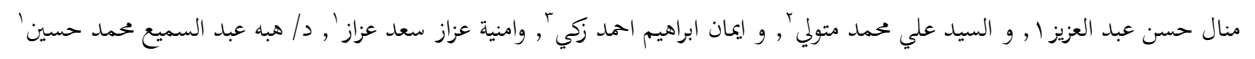

\section{الملخص العربي}

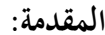

إن الفورمالديهايد هو مركب طبيعي يستخدم على نطاق واسع كمادة حافظة للجثث في أقسام التشريح في كليات الطب. و لقد

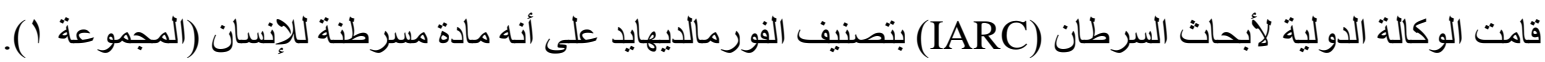

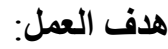

فحص مدة التعرض كعامل محدد في السمية الجينية و المظاهر السريرية للتعرض للفورمالدهيد باستخدام اختبار النواة الاقيقة ، وربط المظاهر السريرية بالتأثيرات السامة للجينات ، وكذلك قياس مستويات هو اء الفورمالديهايد في غرف التشريح بكلية الطب بالإسكندرية، مصر.

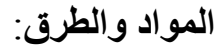

طُلب من كل المشاركين في البحث ملء استبيان مصدم مسبقًا لتقييم العلامات والأعر اض السريرية للتعرض وللتحقق من معايير الاستبعاد كما تم جمع الخلايا الظهارية الثدقية مرنان من · ع طالبًا جامعيًا قبل وبعد شهر واحد من التعرض ، ومرة واحدة من • 1 من أعضاء هيئة التدريس شاركو ا في فصول علم التشريح. نم صبغ خلايا المجموعتين بطريقة فولجين وتم تطبيق اختبار النواة الدقيقة. و أيضا نم قياس مستويات الفورمالديهايد في الهواء في ؟ مختبرات تشريح باستخدام MIRAN-IR. النتائج: كان متوسط

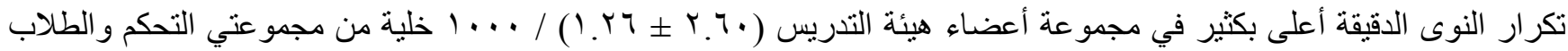
( • • • دلالة إحصائية بين عدد النوي الدقيقة والأعر اض الجلدية و الأعر اض بالعين والجهاز التنفسي. و قد كان متوسط مستوى الفورمالديهايد

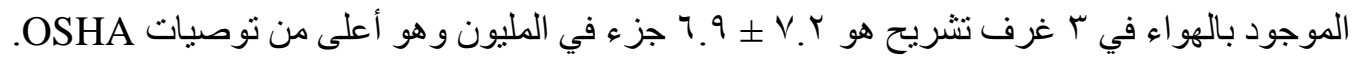

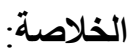

تعتبر مدة التعرض من المحدات الهامة في السمية الجينية للتعرض للفورمالديهايد و قد ارتبطت المظاهر السريرية للتعرض للفورمالديهايد مع عدد النوي الدقيقة ولقد تعرض المشاركون في الدراسة لتركيزات عالية من الفورمالديهايد أعلى من المستويات القياسية وفقًا لوقت التعرض.و قد أوصت الدر اسة بوجوب بذل الجهود لتحسين جودة الهو اءو تقليل التعرض خلال فصول التشريح. 